\title{
Using clover/grass silage as a protein feed for dairy bull calves
}

\author{
Birgitta JOHANSSON ${ }^{1}$, ANNA HESSLE ${ }^{1}$, KARL-IVAR KUMm ${ }^{1}$
}

Key words: clover silage, protein, dairy bull calf, feed intake, live weight gain, profitability

\begin{abstract}
Calves need high concentrations of protein with high protein quality in their feed ration for proper growth. Soya bean meal is widely used in the world as a protein feed of good nutritional quality but the environmental impact of the cultivation of the beans are often questioned. Home grown or locally produced feeds, such as nitrogen fixating forage and grain legumes as well as rapeseed products, are shown to give less contribution to environmental problems than imported feeds. The objective of the study was to compare dry matter intake, live weight gain, feed efficiency and profitability in calves fed two levels of forages with high inclusion of red clover together with two different amounts of rapeseed cake vs. soya bean meal. Soya bean meal gave the highest live weight gain and the best profitability. However, a greater amount of rapeseed together with clover/grass silage also gave a good live weight gain and profitability, close to the results for soya bean meal.
\end{abstract}

\section{Introduction}

Feeding high levels of forages to ruminants is consistent with organic production. However, calves need high concentrations of protein with high protein quality in their feed ration for proper growth. Nitrogen fixating forage and grain legumes as well as rapeseed products can be used. Forage legumes have many advantages, not at least environmentally, but feeding forage legumes only may result in low weight gain as the protein in forages have a high proportion of rumen degradable protein. However, feeding forage legume silage has been shown to increase dry matter intake (DMI) and an accompanying higher live weight gain (LWG) in growing cattle compared to grass silage (Dewhurst et al. 2009). Locally produced feeds other than forage legumes, such as rapeseed, are shown to give less contribution to environmental problems than imported feeds (Flysjö et al. 2008). Soya bean meal is widely used in the world as a protein feed of good nutritional quality but the environmental impact of the cultivation of the beans are often questioned and, furthermore, hexane extracted soya beans are not allowed in organic production. The objective of the study was to compare DMI, LWG, feed efficiency (FE) and profitability in calves fed two levels of forages with high inclusion of red clover together with rapeseed cake (CRC) vs. soya bean meal (SBM).

\section{Material and methods}

The experiment was carried out at Götala Beef and Sheep Research Station, Swedish University of Agricultural Sciences, Skara. Dairy bull calves (79 Swedish Red and Swedish Holstein) were used in a randomized design. The protein feeds studied were red clover (Trifolium pratense)/grass silage (50\% each) combined with either smaller amounts of CRC (treatment CGRS; $0.20 \mathrm{~kg}$ per animal and day) or greater amounts of CRC (treatment CGRG; $0.46 \mathrm{~kg}$ per animal and day), which were compared to imported SBM. The DMI and FE were recorded at a pen level (four pens, each with seven calves, per treatment) while LWG was recorded on the individual calves. The calves were weighed regularly and averaged $94 \mathrm{~kg}$ in live weight at the start of experiment, and ended simultaneously at 202, 267 and $290 \mathrm{~kg}$ for CGRS; CGRG and SBM, respectively. A total mixed ration (TMR) consisting of grass silage ( $90 \%$ grass, $10 \%$ clover), rolled barley and vitaminised minerals, together with either CGRS, CGRG or SBM, was fed to the calves. Feed was offered ad libitum once a day. Diets were rebalanced four times according to changed nutrient requirements during time and subsequent increased live weight. Nutrient composition in DM of the grass silage, the clover/grass silage and concentrates were analysed by conventional methods (Table 1). Analyses of DMI and FE were done with PROC GLM and the model included treatment, whereas PROC MIXED was used for analyses of LWG and the model included treatment and calf nested within pen (SAS 2003). Results with a $P$-value lower than 0.05 were considered as significant and results with $P$-values between 0.05 and 0.10 were considered as tendencies to significance.

\footnotetext{
${ }^{1}$ Swedish University of Agricultural Sciences, Department of Animal Environment and Health, Sweden, www.slu.se/husdjurmiljohalsa, eMail: birgitta.johansson@slu.se
} 
Table 1. Nutrient composition (means) of grass silage, clover/grass silage and cold-pressed rapeseed cake and soya bean meal used in the experiment, shown as $\mathrm{g} \mathrm{kg}^{-1}$ dry matter (DM) if nothing else is stated

\begin{tabular}{l|l|l|l|l} 
& Grass silage & Clover/grass silage & Rapeseed cake & Soya bean meal \\
\hline DM (\%) & 40 & 33 & 89 & 86 \\
\hline ME (MJ kg ${ }^{-1}$ DM) & 11.2 & 10.8 & 16.2 & 14.0 \\
\hline Crude Protein & 124 & 144 & 330 & 523 \\
\hline Crude Fat & na & na & 199 & 25 \\
\hline Ash & 63 & 83 & 64 & 65 \\
\hline NDF & 522 & 410 & 235 & 138
\end{tabular}

ME - metabolizable energy

na - not analysed

The profitability was calculated as value of calf growth less cost of feeds consumed at 2013 price level in Southern Sweden. In sensitivity analyses different prices were used. It was supposed that differences in calf weights at the end of the experiments would remain until slaughter as young bulls at 18 months of age. Thus, the value of $\mathrm{kg}$ calf growth was calculated as carcass price multiplied by dressing percentage.

\section{Results}

Feeding clover/grass silage with a small amount of CRC (CGRS) resulted in lower DMI, LWG and FE than feeding a greater amount of CRC (CGRG) or the SBM diet (Table 2). Feeding the calves CGRG gave the same DMI as the SBM diet, but lower LWG and FE. The intakes of metabolisable energy (ME), crude protein (CP) and neutral detergent fibre (NDF) were the same for CGRG and SBM calves but the intake of NDF in percentage of live weight was higher for the CGRG calves, which might have reduced their total intake in comparison to the SBM calves. The diets in the trial were not balanced to be isonitrogenic as we wanted to test the possible weight gain with feeding high levels of forage, and the forage percentage was 54,66 and 84 for the SBM, CGRG and CGRS calves, respectively. The forage level in CGRG is consistent with organic standards and the daily LWG was just $0.13 \mathrm{~kg}$ lower with rapeseed cake and clover/grass silage as the only protein source, than the LWG in SBM calves.

Table 2. Average daily intake, average daily live weight gain and feed efficiency of bull calves fed diets containing either clover/grass silage with smaller amount of cold-pressed rapeseed cake (CGRS), clover/grass silage with greater amount of cold-pressed rapeseed cake (CGRG), or soya bean meal (SBM), means and standard error of the means (SEM)

\begin{tabular}{|c|c|c|c|c|c|}
\hline & CGRS & CGRG & SBM & SEM & $P^{1}$ \\
\hline Intake of dry matter $\left(\mathrm{kg} \mathrm{day}^{-1}\right)$ & $3.95 a$ & $4.94 b$ & $4.99 \mathrm{~b}$ & 0.141 & $\star \star \star$ \\
\hline Intake of dry matter (\% of live weight) & $3.12 \mathrm{a}$ & $3.02 \mathrm{a}$ & $2.83 b$ & 0.048 & ** \\
\hline Intake of NDF $\left(\mathrm{kg} \mathrm{day}^{-1}\right)$ & $1.45 \mathrm{a}$ & $1.74 \mathrm{~b}$ & $1.77 \mathrm{~b}$ & 0.048 & ** \\
\hline Intake of NDF (\% of live weight) & $1.11 a$ & $1.03 \mathrm{~b}$ & $0.97 \mathrm{c}$ & 0.016 & *** \\
\hline Intake of metabolizable energy ( $\mathrm{MJ}$ day $^{-1}$ ) & $45.6 a$ & $60.8 b$ & $63.1 b$ & 1.76 & *** \\
\hline Intake of crude protein $\left(\mathrm{g} \mathrm{day}^{-1}\right)$ & $581 a$ & $722 b$ & $778 b$ & 22.5 & 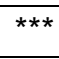 \\
\hline Live weight gain $\left(\mathrm{kg} \mathrm{day}^{-1}\right)$ & $0.717 a$ & $1.147 b$ & $1.279 \mathrm{c}$ & 0.044 & *** \\
\hline Feed efficiency (g gain $\mathrm{MJ}^{-1} \mathrm{ME}$ ) & $15.7 \mathrm{a}$ & $18.9 \mathrm{~b}$ & $20.2 \mathrm{c}$ & 0.29 & *** \\
\hline
\end{tabular}

$1_{\star \star} P<0.01,{ }^{* \star *} P<0.001$, values on the same row that are significantly different $(P<0.05)$ have different superscripts $(a, b, c)$.

Highest profitability per calf in the basic price situation had SBM. However, in organic production with SBM price above $0.90 \mathrm{EUR} \mathrm{\textrm {kg } ^ { - 1 }}$, or with a combination of barley price above $0.28 \mathrm{EUR} \mathrm{kg}^{-1}$ and silage price below $0.11 \mathrm{EUR} \mathrm{kg}^{-1}$ DM, CGRG will become most profitable. 


\section{Discussion}

The fact that calves fed CGRG had the same intakes of ME and CP as SBM calves, but lower LWG, is probably due to the high CP degradability in the rumen of the clover/grass silage. Feeding greater amounts of CRC gave a higher LWG than when calves were fed small amounts of CRC and it is possible that the rumen microbes of the CGRG calves produced more microbial protein that could be enzymatically degraded and absorbed in the small intestine. Feeding energy and protein at the same time is a way to optimize the protein utilisation (Børsting et al. 2003). In the present study total mixed ration feeding was used and thus energy and protein were offered simultaneously. Also, if the CP concentration in the clover/grass silage had been higher the LWG probably had been higher.

Rearing of organic dairy bull calves can be contradictory, using calves with a high need for quality protein at the same time as a high intake of forage ( $>60 \%$ up to 6 months of age) is required. Forage legumes contain more crude protein than grass, but with high rumen degradability of the protein. When legume forage is fed together with energy-rich cold-pressed rapeseed cake (CRC) the protein in the feeds can be utilized to a higher extent and a satisfactory calf weight gain can be achieved as shown. Using locally produced protein feeds instead of the often used soya bean meal (SBM) is of great interest not only in organic but also in conventional feeding because of environmentally advantages.

\section{References}

Børsting CF, Kristensen T, Misciattelli L \& Hvelplund T (2003): Reducing nitrogen surplus from dairy farms. Effects of feeding and management. Livestock Production Science 83, 165-178.

Dewhurst RJ, Delaby L, Moloney A, Boland B \& Lewis E (2009): Nutritive value of forage legumes used for grazing and silage. Irish Journal of Agriculture and Food Reserach 48, 167-187.

SAS (2003): User's Guide. Release $9.1 \mathrm{Ed}$. Cary, NC, USA. SAS Institute Inc.

Flysjö A, Cederberg C \& Strid I (2008): LCA-databas för konventionella fodermedel. The Swedish institute for food and biotechnology, Swedish dairy association and SLU. (In Swedish) 
JohansSOn B, HESSLE A, KUMm K-I 